\title{
Of Women Tech Pioneers and Tiny Experts of Ingenuity
}

\author{
Skúlína Hlif Kjartansdóttir ${ }^{\star t}$, Torfi Hjartarson ${ }^{\dagger}$ and Svava Pétursdóttir ${ }^{\dagger}$ \\ School of Education, University of Iceland, Reykjavik, Iceland
}

This paper presents findings from a collective case study focusing on the efforts of a grassroots team of seven pioneering women: teachers, IT consultants, and tech enthusiasts. The team was formed to introduce, encourage, and establish makerspaces in the Icelandic compulsory school system by educating and supporting teachers and young students (6-15 years) as makers and advocates of maker culture. All seven team members have developed or supported different models of makerspaces in their area of work and offered guidance to other educators. Our research examines learning on a personal, relational, and institutional level, reviewing values and practices of participants and what characterizes their social interactions, agency and empowerment in relation to making. It introduces new models of pedagogy, often supported by school leadership and social media action facilitating the development of making and maker culture. It attempts to map how makerspaces can be integrated into school practice in alignment with curricular objectives to support diverse engagements, digital literacies and creative design skills. Our findings further reveal how an all-women team has taken agency and through collaborative actions, collective creativity and self-empowerment managed to overcome challenges and provide leadership in this emergent field in Icelandic school practice.

Skúlína Hlif Kjartansdóttir orcid.org/0000-0001-6817-5462 Torfi Hjartarson orcid.org/0000-0003-4382-6331

Svava Pétursdóttir orcid.org/0000-0002-1206-8745

Specialty section:

This article was submitted to

Digital Education,

a section of the journal

Frontiers in Education

Received: 25 February 2020

Accepted: 07 August 2020

Published: 04 September 2020

Citation:

Kjartansdóttir SH, Hjartarson T and Pétursdóttir S (2020) Of Women

Tech Pioneers and Tiny Experts of Ingenuity. Front. Educ. 5:160.

doi: 10.3389/feduc.2020.00160

Keywords: makerspaces at school, cross-disciplinary learning, agency, collaboration, collective creativity, technological literacy, gender and makerspaces, empowerment

\section{INTRODUCTION}

This paper presents findings from a collective case study in Iceland focusing on the collaborative efforts of an all women grassroots team of teachers, teacher consultants and tech enthusiasts in administrative or consulting positions at different sites. The group was formed to introduce and establish makerspaces within the compulsory school system, by encouraging and supporting teachers and students as makers and advocates of a maker culture. The team, referred to hereafter as the team, is made up of seven pioneers who joined forces in 2016, determined to gain the knowledge and skills they would need to enable themselves and other educators all over the country to develop makerspaces as an integrated part of daily school practice. Their intention has been to foster interdisciplinary and technology enhanced learning (Sheridan et al., 2014), creative collaboration (Sawyer and DeZutter, 2009; Nasciutti et al., 2016), technical literacy (Dakers, 2014) and design skills (Iversen et al., 2016) within primary and lower secondary schools for students 6-15 years of age. They work toward self-empowerment (Clapp et al., 2017) and knowledge creation through tech meetings and web dissemination, course development, educamps (Leal Fonseca, 2011) and 
practical activities in schools, hoping to establish a network of different interest groups and public agencies in the educational sector.

We explore the nature and impact of this gendered initiative and the dispositional transformations it may have promoted among team members. We also examine the context of makerspaces initiated and laid out by team members in schools and their apparent potential to promote learning as play (Stetsenko and Ho, 2015), creativity (KEA, 2009), curricular integration across disciplines (Drake and Burns, 2004), collaboration and peer learning (Corsaro, 1985, 1997). Our research questions can be regarded from a gendered perspective and summed up as follows:

- What characterizes the personal standpoints, beliefs and practices within the team, regarding the purpose and value of makerspaces?

- How and to what extent have individual group members and the team, encouraged and established makerspaces in educational contexts?

- How has the all-female collaboration impacted the team members' agency and professional development?

The aim of our research project is to throw some light upon how a collaborative and collective approach in this all women team of pioneers has encouraged the endeavors of team members and had an empowering impact on their professional development or disposition, as well as explore to some extent how makerspaces have been promoted, placed and developed in schools or other formal settings where members of the team have been professionally active. Existing research on makerspace culture seems to indicate considerable gender bias and we consider it important, not only to critically examine the access and needs of girls attending makerspaces in educational settings, but also consider the conditions, opportunities, and impact of women initiating and leading such spaces.

\section{BACKGROUND AND THEORETICAL FRAMEWORK}

The following sections outline key concepts and the theoretical framework underpinning our research efforts. We also give an account of favorable conditions and eventual challenges when it comes to making and makerspaces in the Icelandic compulsory school system.

\section{Makerspaces, STEM and Gender}

Our theoretical approach is located within the post-Vygotskian tradition, which assists us in making sense of how young makers learn through culturally and situated activities (Vygotsky, 1978; Kontopodis and Kumpulainen, 2020). It also taps the vein of writings of Engeström (1987) on expanded learning and Stetsenko (2018) on the transformative activist stance (TAS) that considers the relationship of agency and creativity as a driver of human action and that of education as having a role as a social equalizer and potential domain for social transformation. It focuses on interaction, tensions and contradictions of the activities observed and, in this case, particularly, different aspects of a gendered approach that might impact attempts to bring about learning and transformation of learners in school communities. Children are not born users of digital technologies but learn to use them either on their own through interest driven, selfsustained learning (Barron, 2006) or with the assistance of parents, teachers and peers (Corsaro, 1997). Gendered aspects in that respect need to be considered and should be looked upon as being of essential importance in the context of our study.

Makerspaces (Marsh et al., 2017) provide public access to expert knowledge and equipment for digital design and fabrication. School makerspaces may encourage interdisciplinary work and take on different forms, for instance as classroom makerspaces, school library makerspaces, temporary set-ups or mobile makerspaces. They may also require a review of teaching and learning practices depending on their context and situation (Tan, 2018). The act of making:

\section{...is a playful exploration of tools and materials to design personally meaningful artifacts, providing a particularly impactful entry point for traditionally underrepresented youth in science, technology, engineering, and mathematics (STEM) fields (Keune et al., 2019, p. 368)}

Keune et al. (2019) point out that it is "unclear how these explorations translate to eventual professional or educational STEM opportunities, especially for women" (p. 369). Makerspaces may well be one of the most exciting current options in school development, but signs are indicating that a lack of focus around culture and gender might prevent them from fulfilling their promise and make them sites for maintaining inequality. A qualitative research project involving students, instructors and leadership of around 30 makerspaces across 12 urban regions in the United States illuminates this issue (Guiso et al., 2008; Kim et al., 2018). A careful look at cultural aspects, such as the curriculum, attitudes toward competition and instructor interaction with student makers, revealed how the culture of making affects learning. Amongst the findings, reported by Noonoo (2018), was a troubling lack of women in makerspace leadership, as well as pronounced tendency to see boys as more tech-proficient than girls. For the programs examined by Kim et al. (2018), men occupied 76 percent of all leadership roles, while women held only 24 percent. Gender parity among students was observed in early grades but the participation of girls dropped by 25 percent between the 8 th grade and high school. Identity references showed considerable gender bias, with instructors referring to male students as "geeks," "builders" and "designers" (never "boys"), while female students were frequently referred to as "girls" or "helpers" (Kim et al., 2018, p. 4). Boys were twice as likely to hold leadership positions and steer major project topics. The researchers also observed a gender disparity in expressed design agency (ability to design or guide project activities) in formal vs. informal learning makerspaces, with boys expressing greater agency in formal spaces, but girls expressing greater agency in informal spaces. The report indicates a direct impact of makerspace culture on students-their learning, participation, mindset, collaboration and sharing with others-and concludes that designers of new makerspaces should consider the kind of 
learning culture they seek to create for their students before choosing equipment or outlining specific projects.

The culture of makerspaces can be related to educational movements coined STEM (Science, Technology, Engineering and Mathematics) or STEAM (includes Art), as the subject areas they promote tend to be directly tied to making and maker projects. Women in most countries are underrepresented in professions attached to STEM and only make up $14.4 \%$ of that sector in the United Kingdom (Gjersoe, 2018). There can be reasons why girls stay away from this sector of professional activity, reasons like stereotyping and the lack of female role models, that could as such be regarded as hindrances in learning. A recent research on student academic performance, role of motivation and perceived factors hindering learning identified several hindrances, among them gendered factors. It concluded that learning hindrances had a more negative impact on female students and that alleviating these challenges could foster increased girls' enrolment, retention, and completion rates (Gbollie and Keamu, 2017).

Research consistently shows that boys and girls are on average more similar than different across a range of skills of significance in this respect. A critical review of gender differences in math (Spelke, 2005), based on a 100 studies, found that girls outperformed boys overall in primary school, that there was no difference in achievement between male and female students of math in secondary school, except for a very slight and inconsistent male advantage when it came to complex problem solving. Different cognitive profiles detected among older boys and girls tended to be small and reflect differing strategy choices. Spelke (2005) concludes that cognitive factors do not explain gender disparities in this respect and points out that we need to look to other aspects of human biology and society for insights.

Guiso et al. (2008) used PISA data to look at gender differences in math performance among 15-year-old students. They found that girls' math scores averaged 10.5 points (2\%) lower than the mean average for boys, but this difference varied by country. A recited example from Turkey showed an even greater gender gap (boys outperformed girls by 22.6 points) while in Iceland the gender difference was reversed (girls outperformed boys by 14.5 points). By comparing countries according to several measures of gender equality the researchers presented evidence indicating that girls' underperformance in math relative to boys had been eliminated in the more gender-equal cultures. This might suggest that a gender-equal culture could have an equalizing effect in STEM areas of education. The introduction of both makerspaces and STEM or STEAM into compulsory school practice needs not only to be regarded as an educational effort to promote digital technologies and 21st century skills, but also reviewed considering cultural aspects involving equality and inclusion, paying close attention to gendered interest, choice and participation.

Researchers in Sweden (Tellhed et al., 2017) recently tested self-efficacy (competence beliefs) and expectations regarding social belongingness (fitting in socially) as mediators of gender differences in interest in STEM and HEED (Health care, Elementary Education, and the Domestic spheres) among 1.327 high school students. Gender differences in interest in STEM appeared strongly related to women's lower self-efficacy for STEM careers and, to a lesser degree, to women's lower social belongingness expectations with students in STEM. Social belongingness expectations also partly explained men's lower interest in HEED majors, but self-efficacy was not an important mediator of gender differences in interest in HEED. The researchers concluded that efforts should be made to strengthen the sense of social belongingness among students in the gender minority. To increase women's interest in STEM, it would be needed to counteract gender stereotypical competence beliefs and assure women that they have what it takes to handle STEM careers.

Iceland has a reputation for an advanced status of women regarding equality (Ólafsdóttir and Rögnvaldsdóttir, 2015). It has had laws on equal right of the sexes since 1976 (Law nr. 78/1976, 1976) and became in 2018 the first country to legalize equal pay for women and men (Law nr. 56/2017, 2017). As in most countries from the 19th century onwards women's collaborative movements have regularly surfaced for support, womens' rights, equality and solidarity, most notably Kvenréttindafélagið (Styrkársdóttir, 1999), Rauðsokkahreyfingin (Kristmundsdóttir, 1989) og Kvennalistinn (Jónsdóttir, 2020), that brought women together for womens' interests and political impact. Iceland is, according to the Global Gender Gap Report 2020, the most gender equal country in the world, 11 years running (World Economic Forum, 2019). It is therefore a matter of some consideration to find women in minority when it comes to attendance of university courses in the areas of science and engineering (National Statistical Institute of Iceland, 2020). Despite attempts in Iceland and elsewhere to foster inclusive engineering and computing cultures, most STEM fields remain a predominantly masculine domain (Keune et al., 2019). Girls in Denmark, France, Iceland, and Sweden have also measured considerably lower than boys when it comes to self-efficacy in the area of science (UNESCO, 2017). This is, however, a situation that the broader maker movement has acted on with specific projects in order to engage young girls in STEM (Keune et al., 2019).

Studying technology from a gender perspective often shows how technological artifacts are designed and shaped by gender relations through their uses and meanings, perpetuating differences and relations of power (Costa, 2008). This could also be revealed by researching and analyzing the social construction of technologies, their accessibility and the discourse surrounding the technological field in question. Earlier feminist theorists analyzed women as victims of technologies, but a more contemporary feminist, Wajcman (2010), stresses the mutual shaping of gender and technology, in which technology is both a source and consequence of gender relations. The gender-technology relationship is fluid and situated. She points out that the processes of technical change can influence gender power relations and that the politics of technology are, therefore, a key to achieving gender equality. By starting to examine the gendered dimension in everyday life, ICT and education, that are often overlooked, 
we are increasing our understanding of this mutual shaping of gender relations and technology - 'gendering the digital' (Green and Singleton, 2013).

\section{Agency and Empowerment}

Makerspaces are already being introduced worldwide in schools at different levels (The Nmc/CoSN Horizon Report, 2017). The inclusion of coding and robotics, when successful, allows students to experiment and create in ways that invite complex thinking, resilience, active and interdisciplinary learning. Educational theories of 'making' and 'digital fabrication' refer to experiential education, constructionism, emancipatory and critical pedagogy (Blikstein, 2013; Jónsdóttir and Gunnarsdóttir, 2017). The maker movement emphasizes the pedagogical value of problem finding and problem solving, and the power of social learning through sharing and collaborative work (Smith and Smith, 2016). The work and projects undertaken in makerspaces are often characterized by collective knowledge creation (Hughes et al., 2019) and collective creativity (Sannino and Ellis, 2014). Furthermore, making encourages intellectual risk taking through iteration, drafts and failed attempts leading students to value learning as a process (Vossoughi and Bevan, 2014).

Developing agency (Emirbayer and Mische, 1998) is an essential process that happens through communal production and sharing with peers. It is manifested in children's attempts to gain control over their own lives (Corsaro, 1985). During these attempts, tensions and conflicts may arise, but these can be relieved by negotiations, collaboration and a growing ability to socialize, communicate and interact with others. Agency grows from practical activities and social interaction where external operations are reconstructed in a process of internalization, inside the child. Peer interaction and the child's appropriation of its society and culture, therefore, play an important part in child development and education, along with adults' guidance (Corsaro, 1997). This implies that the child or person is not only subject to socialization, but also active in the formation of society. New ideas and powerful tools for digital fabrication and making demand new forms of expression and empowerment for young learners (Clapp et al., 2017; Marsh et al., 2017), encouraging creativity and establishing basis for self-expression and literacies. Maker education can in this sense be seen to run counter to trends of accountability in education and managing by numbers (Maslyk, 2016). Maslyk stresses that "the notion of citizens and makers, not consumers, connects to the mindset that is growing the maker movement and STEAM education" (p.4).

The advent of makerspaces can also encourage teachers' professional development, empower them to try out new technologies and introduce pedagogical models that are future oriented. This requires acquisition of knowledge and training, experimentation and self-study, if training opportunities are not forthcoming. Teachers need to build a repertoire of work with various materials, advanced technical equipment or software applications, develop abilities to teach design literacy and establish new educational practices (Oliver, 2016). They must be ready to implement appropriate pedagogies and teaching methods, use complex technologies, solve technical problems and adapt to new circumstances (Demetriadis et al., 2003; Hennessey and Deaney, 2004; Hira et al., 2014). Research has confirmed the importance of teachers in this respect, as playing the roles of both a traditional instructor and a facilitator, approaching teaching and learning in a social constructivist manner and providing students with the appropriate flexibility for ideation, experimentation and meaning making (Bauersfeld, 1995; Gunnarsdóttir, 2001; Thorsteinsson, 2013; Jónsdóttir and Gunnarsdóttir, 2017). Furthermore, teachers need to harmonize the implementation of makerspaces with national laws on education, core curriculum guides (Ministry of Education Science and Culture, 2014) and, in the Icelandic case, with their own school curriculum or agenda, that they themselves have taken part in developing.

\section{Facilitating Conditions and Challenges}

Craft education has been firmly rooted as a range of subjects in Icelandic compulsory school practice from the outset of public schooling (Ólafsson and Thorsteinsson, 2013). Efforts to establish innovation and entrepreneurial education in Icelandic compulsory schools have fostered entrepreneurship and cooperation, but only of late put student activities focusing on digital technologies at the forefront (Jónsdóttir, 2011). Fab labs, first founded in Iceland in 2008, introduced makerspaces and digital fabrication as an informal, educational opportunity to the general public, startup companies and the educational sector (Nýsköpunarmiðstöð Íslands, 2018), but it is only recently that makerspaces are being integrated or established at a handful of compulsory schools. The makerspace, as a concept and educational opportunity, is just beginning to gain foothold within Iceland's formal education system, while significant conditions facilitating making in schools, such as the vocational subject areas and infrastructure mentioned above, are already in place.

Another condition paving the way for making and makerspaces is the directive role that the national core curriculum (Ministry of Education Science and Culture, 2014) provides, encouraging teachers to innovate, integrate subjects and look at equality, creativity, sustainability and literacies in a broad and integrated sense, as foundational pillars of all learning. The establishment of makerspaces has the potential to connect to the values of the curriculum. The implementation is often context dependent and likely to turn out different pedagogical models. A positive legal framework should help to provide open and flexible conditions allowing for agentic action and eventual empowerment of participants. Yet another favorable condition is a widespread enthusiasm around mobile technologies, cloud solutions and plethora of software, accompanied by a growing interest in digital media production projects, programming and robotics suited for young students.

Challenges are evident in implementation of school makerspaces, as can be expected for any major school development. Hira et al. (2014) identified four broad categories of challenges that need to be overcome for innovative practice of makerspaces to be successful. Firstly, they mention standardized tests that guide educators in curricular decisions, resulting in "zero-sum curriculum in which the essential, tested subjects take 
precedence over non-tested subjects, eventually pushing them completely out of the curriculum" (pp. 1679). This has an added effect with respect to pedagogy, standardized tests have "a greater impact on the content and pace of instruction than the mode of instruction" (pp. 1679), resulting in less and less time allocated for assignments other than explicit test preparation, regardless of their educational value. Secondly, a considerable amount of teacher preparation is needed to implement makerspace programs, requiring the teacher to have a deep understanding of the subject matter and relevant pedagogical practices, knowledge of and experience with materials and equipment, as well as sufficient self-efficacy to implement unfamiliar curriculum and deal with upcoming problems. As third, comes the integration of technology and other resources in the classroom, convincing teachers to use it effectively and supporting students in its use. This involves challenges extrinsic to the teacher, e.g., limited equipment, training, support etc., but also teachers' own beliefs regarding teacher-student roles, curricular emphases and assessment practices. These challenges are highly contextual, and their resolution varies according to the situation at each school. The fourth challenge is addressing diversity in engineering design as well as individual diversity, which translates as inclusion of people, including women and underrepresented minorities, with different kinds of experience or needs of significance for the design process. The authors (Hira et al., 2014) consider this diversity an important asset for making in the classroom.

\section{MATERIALS AND METHODS}

The study is intrinsic (Stake, 1995) in the sense, that we have an intrinsic interest in the team and its undertakings, we look at the initiative as something that really calls for attention. It is also a collective case study (Stake, 1995) in the sense, that we will be looking at individuals in different positions, as well as makerspaces manifested in different contexts and at many different sites. It can, furthermore, be regarded as an interviewbased study (Trainor and Graue, 2013), complemented with data from other sources. We base our findings on data gathered for over 3 years: mainly extensive and semi-open or semi-structured interviews with the team as a whole and each of its individual members, but also field visits to several schools, photographs and video-recordings of students at work, as well as selected data from social media communications between members of the team. Our relationship with the team under research is, furthermore, enhanced and substantiated by our long-term acquaintance and manifold ties with some of the team members, through our own involvement in teacher training and developmental activities.

\section{Participants}

The team was formed in the fall of 2016 as a grassroots initiative aiming to establish experimental makerspaces within the compulsory school system and support both teachers and students from 6 to 15 years of age as makers and advocates of maker culture. All group members, seven women, are qualified teachers. Their current age span ranges from 39 to 55 years and their professional experience averages 20.7 years (Table 1).

\section{Group Interviews}

Two group interviews were carried out in the early stages of our research project, partly to establish the objectives of the team. The former one took place in May 2017, with six out of seven team members present. The aim was to determine what had brought members of the team together and sparked their interest in makerspaces, as well as to hear about their ideas and expectations regarding makerspaces at their different school sites or places of work. The latter one was carried out in April 2018, with five team members present, to inquire about the progress of their collaborative efforts and the introduction or development of digital making at their respective sites. The two group interviews were conducted at our university by all three researchers, and totaled $282 \mathrm{~min}$.

\section{Interviews With Individuals}

Interviews with individual team members totaling $623 \mathrm{~min}$ were carried out from December 2019 to June 2020. Each researcher interviewed two or three team members, each member individually, to inquire about her professional background and disposition, how she valued the team and its efforts, what she had been doing to promote making at her site or in her professional position, and how she envisioned the future of the team. The interviews were conducted in a semi-open or semi-structured manner (Trainor and Graue, 2013). They were supported by a list of questions prepared to echo some of our theoretical orientations and research considerations regarding team member practices, views and dispositions, while also enquiring about practical aspects and situational contexts of the makerspaces involved. The questions mainly fell into the following categories: makerspaces and participants' experiences and opinions, students' experiences, makerspaces and schools or the educational system, digital technologies in makerspaces and finally the role and practices of the team.

\section{School Visits and Makerspace Observations}

The researchers visited team members on several occasions at five different schools to carry out class observations, take part in educamps or be present at open days for visiting parents and other guests. We visited a digital media and innovation center run by the city of Reykjavik, a consulting agency and resource center called Mixtura (n.d.), where two of the team members were professionally active as project managers and teacher consultants at the time. Data collected under all these visits include photographs and video recordings of teaching situations and learning sessions (718 min), in particular at the Lab of Ingenuity (see below), where video was recorded using two GoPro cameras, mounted on the foreheads of children to capture human-computer interaction, as well as two stationary cameras to get an overall view of human interaction within a small classroom housing the lab. Photography was used to document technical resources, technologies employed and evidence of learning results in different makerspaces at different sites (423 units). 
TABLE 1 | Team members: age and professional status.

\begin{tabular}{|c|c|c|}
\hline Pseudonym (Years of experience) & Professional status in 2017 & Professional status in 2020 \\
\hline Freyja (16) & $\begin{array}{l}\text { Educational technology consultant at a lower } \\
\text { secondary school in a suburban municipality nearby } \\
\text { Reykjavik. }\end{array}$ & $\begin{array}{l}\text { Project manager and educational technology } \\
\text { consultant representing the city of Reykjavik and its' } \\
\text { digital media and innovation center. }\end{array}$ \\
\hline Frigg (15) & $\begin{array}{l}\text { Project manager and educational consultant in a } \\
\text { suburban municipality ( } 8 \text { schools) nearby Reykjavik. }\end{array}$ & $\begin{array}{l}\text { Project manager and educational technology } \\
\text { consultant representing the city of Reykjavik and its' } \\
\text { digital media and innovation center. }\end{array}$ \\
\hline Gerdur (25) & $\begin{array}{l}\text { Educational technology and innovative teaching } \\
\text { consultant in a rural municipality ( } 3 \text { school sites) on } \\
\text { the western coast of Iceland some } 200 \mathrm{~km} \text { from } \\
\text { Reykjavik. }\end{array}$ & Same position. \\
\hline Idunn (25) & $\begin{array}{l}\text { Project manager and educational technology } \\
\text { consultant representing the city of Reykjavik and its' } \\
\text { digital media and innovation center. }\end{array}$ & Same position, but with different duties. \\
\hline Nanna (21) & $\begin{array}{l}\text { Project manager and digital media consultant } \\
\text { representing the city of Reykjavik and its' digital } \\
\text { media and innovation center. }\end{array}$ & Same position, but with different duties. \\
\hline Sif $(30)$ & $\begin{array}{l}\text { School library teacher at a primary and lower } \\
\text { secondary school in Reykjavik. }\end{array}$ & Headmaster at a primary school in Reykjavik. \\
\hline Sigyn (13) & $\begin{array}{l}\text { Teacher and teaching consultant in a primary and } \\
\text { lower secondary school in Reykjavik. }\end{array}$ & $\begin{array}{l}\text { Teaching consultant at a primary and lower secondary } \\
\text { school in an urban municipality nearby Reykjavik. }\end{array}$ \\
\hline
\end{tabular}

\section{Website and Social Media}

In addition, we collected data from the teams' website, Snillismiðjur (Vexa group, n.d.), as well as the teams' Facebook teacher community group on school makerspaces, Makerspace á Íslandi (n.d.). We are, for the purpose of this paper, mostly making use of data from the interviews, while other data serves to support and throw further light on our findings.

\section{Data Analysis}

Observation notes, photography, and video recordings from our field visits were only reviewed to a certain extent as support material for our interview data. We focused our analysis of this data on agency and interaction from a gendered perspective, as well as conditions defining the freedom of creativity and decision making among students involved in making. Data from social media was reviewed mainly to inform about the group's contribution to the teacher community and confirm selected findings drawn from theme analysis of interview data.

The interview data was transcribed and analyzed employing thematic analysis, listening to the interviews repeatedly while drawing out insights in response to research questions and theoretical points of view. Data analysis of interviews with individual team members resulted in five main themes and over seventy sub-themes. The main themes were school practices and pedagogy, ideology and implementation of makerspaces, experiences and insights of team members, operations of the team and future aspects. Thematic analysis is considered a realistic and flexible method for identifying, analyzing and reporting patterns or themes across a dataset (Braun and Clarke, 2013). The method is not tied to any theory and is now recognized and widely used in different fields of social science. It is, as described by Braun and Clarke (2013), a systematic six-phase process that can be outlined as involving:
- Observation and reading of data - recording of initial ideas

- Coding or classification of data to analyze underlying meaning

- Discovery of shared patterns based on codes or classifications

- Theme analysis - connecting codes or classes that refer to themes, observing themes and sometimes re-evaluating them

- Theme analysis and naming final themes

- Findings drawn and written up

The themes can be identified in different ways, in a data-driven 'bottom-up' way, based on what the data contains, or identified in a more 'top-down' fashion when the researcher approaches the data to explore particular theoretical ideas. The two different approaches are sometimes combined in the same analysis. This turned out to be a productive approach for this research as the theories and research questions guided some of the analysis, while the interviews also produced insights that were informative about the practices observed.

\section{Ethical Issues}

Our study is a part of an international research project, MakEY or Makerspaces in the Early Years (MakEY, 2018). Ethical issues and arrangements have been administered centrally and agreed to by all partners, including scientific committees at the University of Sheffield and the University of Iceland. Informed consents regarding participation, recordings and application of data material were signed by all participants, including professionals, parents and their children (Dýrfjörð et al., 2020). The practice of informing participating children about the research, its purpose and practices, proved particularly beneficial and helped to gain their trust. No harmful effects of research procedures were observed. 


\section{FINDINGS}

Our findings are presented in three overlapping parts reflecting our three research questions. Selected themes and subthemes from our data analysis were used to draw in data from interviews with individual participants.

We begin by relating how the team was formed and what brought its members together, their shared enthusiasm and disposition toward new technologies, pedagogies and diverse teaching methods in makerspaces and daily school practice. We report how the group has built up its base of knowledge and introduced making to schools and schoolteachers through workshops, courses, social media and other internet resources.

We then move on to describe how group members envision makerspaces in schools and how they have put their ideas into action. We give an account of makerspace facilities under development and supervised by different team members at compulsory schools in three municipalities. We also describe a municipal consulting agency in Reykjavik where four team members have been staff members, promoting the application of digital technologies and media in schools.

The final part gives an account of findings that illustrate how the team has evolved and empowered its members, how they, on their own initiative and through their collaborative efforts, supported to some extent by school leadership and educational authorities, have met with challenges, empowered themselves as experimental pioneers, and taken steps toward professional leadership in institutional terms.

\section{A Female Team of Tech Pioneers - Beliefs and Practices}

Our first group interview with the team was made in the spring of 2017, when the group had just been granted funds to set up an online learning community and organize workshops for teachers around robotics, making and makerspaces. The team had been formed the preceding fall. All seven members had been active advocates of digital technologies in compulsory school practice for years and some had met on occasions at educational technology meetings, where they began to develop a shared vision. Sif invited some ten to twelve women to an informal conversation about makerspaces and shortly after offered those interested from that meeting to join her for a weekend at a summerhouse out in the country, where they would be able to tinker and experiment with digital technologies. Six women accepted that offer, and something fell into place when the group came together.

Suddenly you just [found], because we were not friends before, a kindred spirit [...] it was great to find some people that shared this interest. [...] this is your work, which you're supposed to attend to from eight to five or something, but it is also an interest. You might be hiking or playing bridge, while I am exploring the application of green screen technology in teaching and learning. (Sif)

This chance weekend gathering in the fall of 2016 evolved into a collaborative effort and resourceful learning community. The women involved, when interviewed individually, give vivid accounts of how enthusiastic, supportive and productive the group became after this first encounter:

there are so many ideas and things are decided before you know it. We have at times been driving to a summerhouse in two cars and discovered when we make a stop somewhere that things have been decided in the other car [...] And it's never an issue, it's such a melting pot! (Gerdur)

the most desirable is to have somebody that backs you up, this is for sure [...] they do not always have the answers [...] but you can always reflect with them and we have different backgrounds and interests [...] So, I think that is the greatest advantage of our little learning community! (Freyja)

Our second group interview, carried out in 2018, revealed that each member of the group had been developing her technical knowhow and professional efforts, as well as sharing information about making with a relatively broad audience. Individual participants reported for instance, how they had given workshops at their work sites, organized educamps for teachers and school leaders within their district, and been visited by politicians, the media or educators from distant schools.

Team members related how they used social media to learn, often drawing on resources and inspiration from international interest groups. Frigg commented: "The Icelandic groups are quickly drained." The group had sought inspiration and knowledge by attending a Maker Faire in New York where team members bought extensive supplies of new equipment for their makerspaces. They also visited the BETT show in Britain. They all spoke positively of their own closed Facebook group, referring to it as the best place to look for advice and answers to "silly questions." They further explained how they intended to inform and influence teachers all over the country. The internet "gives us a chance to be visible, to advertise our courses and share, not just our websites, but just interesting things we come across." In the fall of 2017, they created a public Facebook group, containing approximately 800 members in 2020 . They made use of the hashtag \#vexaedu on Twitter, and mediated news on Snapchat. Facebook data confirms that members of the group were actively sharing acquired knowledge via social media and manifests their influence in professional groups exploring and debating the use of digital technology. One indication of their pioneering status appeared early in the summer of 2018, when someone asked all members of the extended Facebook-group if there was a makerspace in operation at their school. Only three members responded by proclaiming to have a permanent makerspace running at their institute, all three women from the team.

The team contributed to the professional development of teachers by offering lectures and courses to teachers interested in digital literacy, technical affordances or pedagogical opportunities involved in making. A team website was published in the fall of 2018, offering collections of valuable links, presenting maker project ideas, and providing information on weekend courses for teachers. Our observation of the delivery of the courses (Figures 1,2) showed a high level of interest among the attending teachers, a broad selection of task-based activities (from making a bath bomb to design thinking and complex digital fabrication), and ample opportunities for attendees to network. 


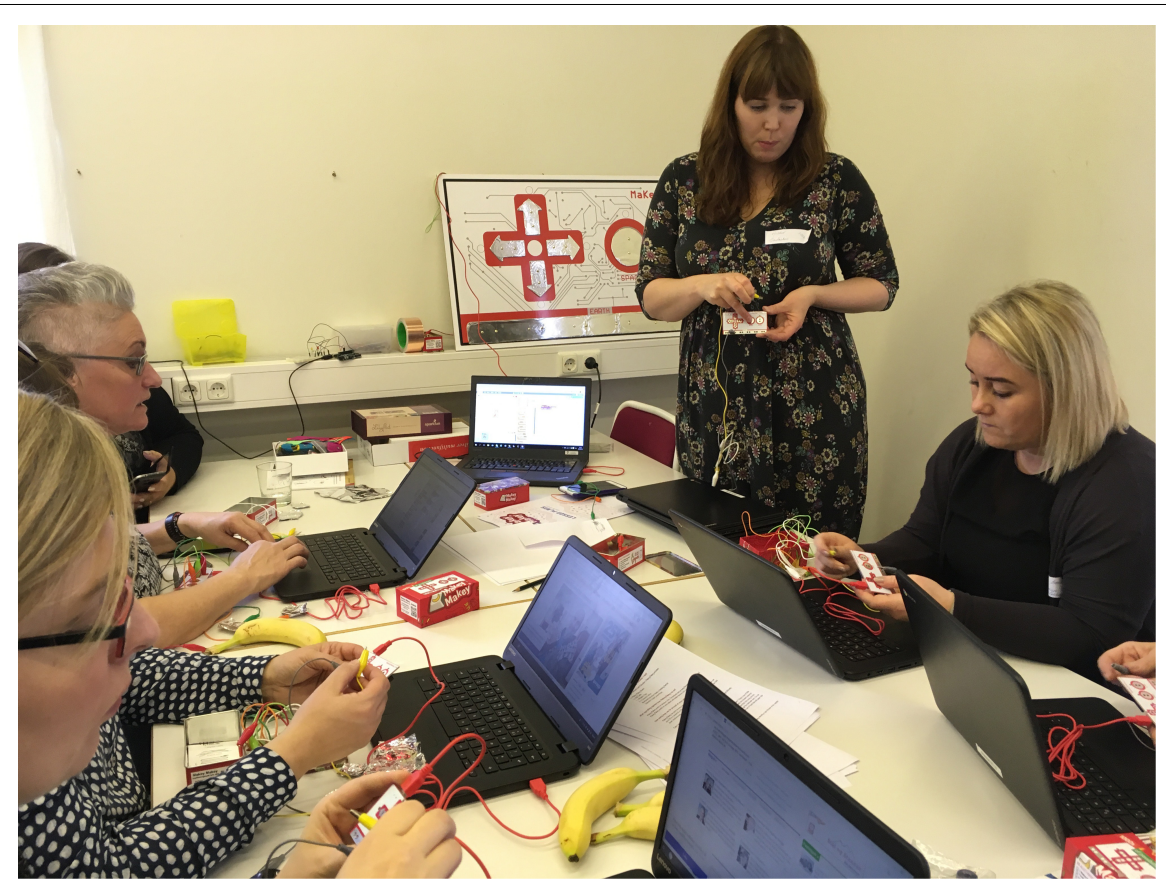

FIGURE 1 | Teachers studying Makey Makey-connectors at a professional learning and training camp in Snaefellsnes, Iceland, led by the team and offered to teachers in September 2018.

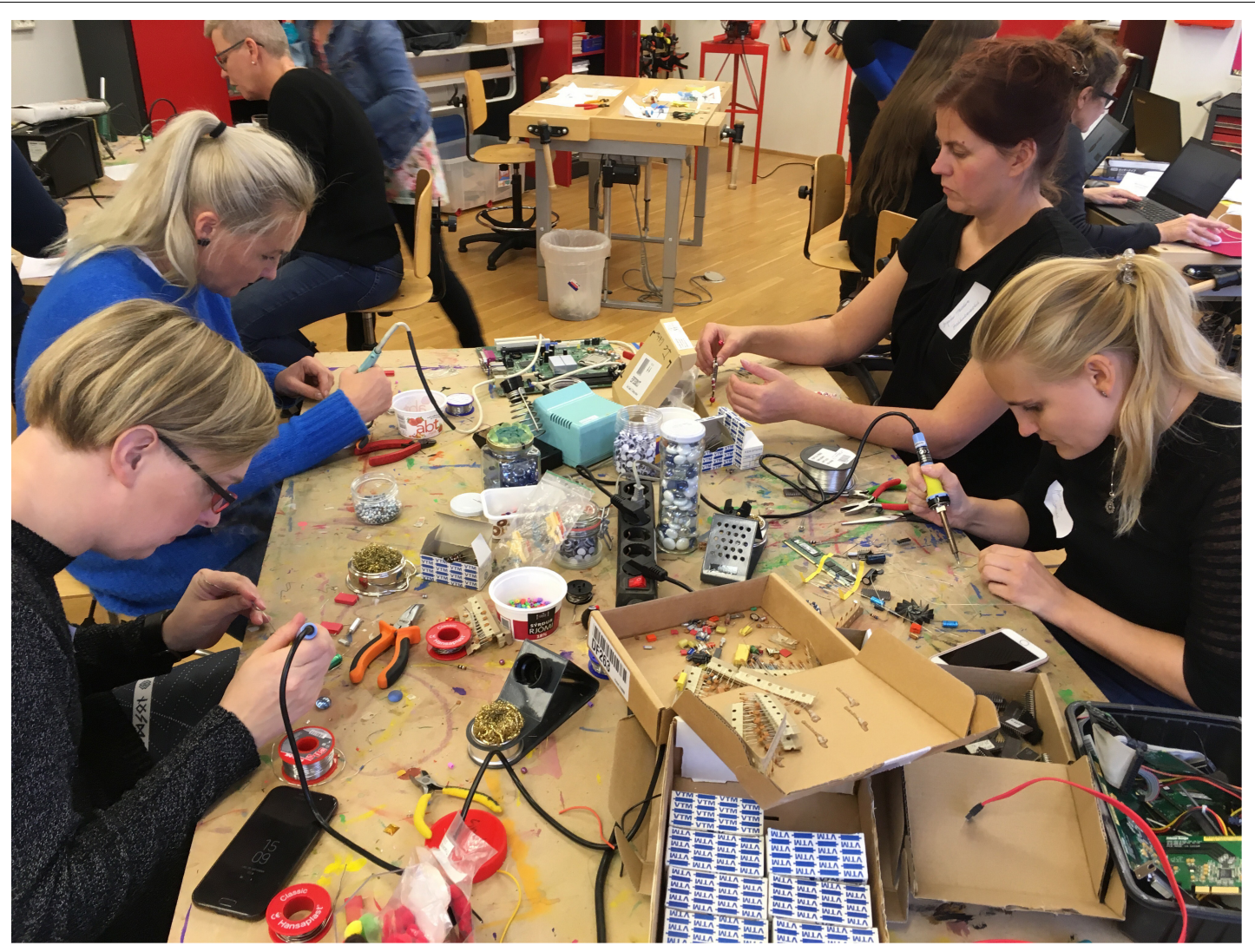

FIGURE 2 | Teachers studying soldering at a professional learning and training camp in Snaefellsnes, Iceland, led by the team and offered to teachers in September 2018. 
Sigyn admits having learned "an incredible amount, arranging and giving courses with the others," while "half of the charm [was] learning from the teachers attending." Team members celebrate their success in this respect and see all of this as an integral and important part of their practice.

What brought them together as a group was, according to Sigyn, "this interest to create with technology and the aim to introduce making and the concept of makerspaces into schools." Others point out their shared dedication and almost burning passion to improve school practice in more general terms, their desire to see a more creative and diverse approach to teaching and learning:

I think it's the pedagogy, wanting to do better in school practice [...] I think that's the biggest factor, that we wanted to see changes

[...] more creativity. [...] We all share a burning interest in school practice, in finding a new perspective. (Gerdur)

Enthusiasm and keen interest in educational change appears to be characteristic for all the team members. Their passion and selfmotivation transpire in their constant willingness to reeducate themselves, to seek new insights through internet resources, courses, conferences and fairs, or to try out new things and share the results with other professionals.

The development of 21 st century skills and efforts to counteract spiritless teaching methods by challenging students and actuating their creative abilities, are among many issues that surface as we inquire about the purpose of bringing makerspaces into schooling. Sigyn talks about project-based learning and collaboration, creativity and analytical thinking. She explains how active learning in makerspaces enables students to exercise "problem-solving and perseverance, all competences that relate to 21st century skills, to think critically, all of those are essential when you are creating with technologies and connecting things." Freyja mentions the development of resourcefulness and resilience. Idunn maintains that school makerspaces should be established to fulfill "the need to develop teaching and learning where individuals can flourish, respect for children, and interest in technology." Many team members mention inclusion in this respect and relate how makerspaces provide opportunities to meet the different learning needs and interests of diverse students with a choice of projects.

Sif sees makerspaces as having the potential to steer students away from school boredom, especially in the middle grades when their "minds are not sufficiently challenged" and books take over as mediators of knowledge. Rather, "their curiosity should be activated, and their creativity encouraged with interest-driven and stimulating projects." Freyja, like many other team members, praises the educational value of playful learning. The following comment illustrates a common view in that respect:

they think this is all play [...] I mean, they were programming Arduino and Python down to the 5th grade, but they thought it was all play. They did not realize that they were learning. (Sigyn)

This notion reverberates in descriptions of design projects or learning tasks promoted or applied by team members, projects that might involve the collective composition of a simple computer game, the construction of a primitive robot, the weaving of an electrified cloth or other work allowing learners to exercise their agency and reinforce their identity. Team members also underline the social nature of learning and point out how teachers can learn from students, just like students from one another.

\section{Makerspaces in the School System}

Makerspaces in educational settings signal changes in instruction, but also in the nature of learning or creation of knowledge and building of competences. They appear in our case to be highly contextual, depending on infrastructure, the expertise of their initiators, and experiences of students. This section provides an account of how makerspaces supervised by team members have been conceived, implemented, supported, and, sometimes, hindered. The members have all been active in setting up makerspaces on temporary or permanent basis, but for different purposes and in distinct settings, such as urban and rural schools, school libraries or a community training facility for teachers. The context, school culture and facilities have varied greatly, and individual members have had to tackle different challenges.

\section{Vision and Potential for Making in Schools}

Most or all team members foresee a shared space freely accessible at every school. Gerdur says: "...it is my dream that we create circumstances where the students can come, get an idea, if they want to fix something, or do something, have a place here to get assistance, equipment, tools or just use YouTube." Some mention that the makerspace could work in conjunction with school libraries or craftwork classroom areas. All members agree that the makerspace needs to be staffed, while teachers need to be involved. Frigg works at a consulting center and says: "there is no point in just sending the kids here, if the teacher is somewhere else. The teacher needs to know what is possible. And what is available." And Gerdur explains how "the teachers come saying: I want to do this. Then we suggest ideas, find a solution and I help them along with the first steps. It is just so that teachers have limited time to explore and find out about things."

Time is also an issue in terms of finding space for making within the curriculum. Some team members find scheduling and making incompatible, maintaining that the timetable should be the first thing to go to make room for creativity, and that longer periods of time are needed for participants to immerse themselves in making projects. Nanna notes: "I just hope that things are changing in tandem with the society we live in."

A goal shared by all team members is to promote more diverse teaching methods, in part by approaching teaching and learning as teamwork across subject areas. Freyja elaborates: "makerspaces, generally, can encourage diversity in methods of instruction, they can also lead to integration of school subjects. So, I think that makerspaces actuate transdisciplinary discussions, especially between school divisions that operate like silos." Sigyn ties the purpose of making in schools to connected learning beyond school walls and the ability to make use of knowledge in a practical way, as opposed to monotone and isolated, bookish learning. Sif sees it relieving school boredom, especially in the middle grades when "their minds are not sufficiently challenged" 
and books take over as mediators of knowledge. She wants "their curiosity to be activated, and their creativity encouraged with interest-driven and stimulating projects." The team members also value the social nature of learning, Sigyn points out that: "teachers can learn from students, just like students learn from one another."

Nanna relates the purpose to the need for valuable skills in prospective work life, saying: "The world does not need rotelearning, the economy needs thinkers and creators." Creativity, problem solving, and critical design thinking are consistent and considerably challenging targets, as Sigyn expresses: "I desperately need to take this further, so that creation can set in." She wants her students to surpass the mastering of basic techniques and be able to use their acquired skills creatively. Freyja, Gerdur and Sif all make a similar notion, feeling the same need to develop their makerspaces in this direction. Freyja explains: "Students are still a bit stuck on the product, they do not realize that they are acquiring digital literacies [...] a competence to create and think [...] I am referring to the design process, it is also a competence, and to be able to collaborate in groups." She talks on to underline the significance of introducing design thinking and design stories to further this understanding and enhance such skills.

\section{Makerspaces in Diverse Schools}

Freyja served as a teacher and IT teaching consultant, actively engaged in making at an urban school for 12-15 years old students. She arranged in conjunction with the school library a permanent makerspace, where students attended making as selective courses. She also wanted to offer the makerspace to "YouTuber sofa types," students who might want to use gaps in their schedules for making rather than lounging along the corridors watching videos. She collaborated successfully with the teacher of textiles on vinyl cutting and clothing but encountered difficulties in sparking the interest of teachers in other subjects. Finding time within rigid timetables for making proved particularly troublesome. She was expecting collaboration with the librarian, but that assumption turned out not to be reciprocal. She created short courses for teachers in her community but did not find much uptake. She has consequently moved on and taken up a job as a tech consultant in the capital allowing her to reach a broader audience among students and educators alike.

Sif served as a school library teacher at a suburban school in the capital for students 6-15 years of age. She repeatedly expressed ambitions to work more intensively with digital literacies in her library but found it somewhat difficult to get teachers at her workplace involved in project work. She made efforts to introduce her vision about making to teachers, organizing carousel work and thematic projects for their class groups, but the teachers appeared to be too heavily involved in collaborative work in their daily routines as members of teacher teams attending large cohorts of students in open plan settings. She was able set up a Lego wall in the school library and remained devoted to her mission of promoting digital literacies and making at her post for a couple of years but eventually decided to move on to another school. She has since then been preparing and developing a permanent makerspace at her school library, urging her fellow teachers to try out technical novelties and digital applications. She has also helped to develop and manage a longterm collaborative makerspace project between three Reykjavik schools (Sköpunarsmiðjur, n.d.), in part by engaging herself and other team members in providing short courses for the teaching staff at all three schools. She has now, just recently, replaced her headmaster and expressed ambitions to direct teachers at her school more firmly to include digital solutions and making in their practice.

Some members of the team share with us memories of playful making and tinkering from their youth. Gerdur relates how children in her fishing village could play on piers and boats in the harbor or imitate farming with miniature turf houses, shells and bones representing buildings and livestock. They would build primitive rafts out of all kinds of material and learn from older siblings, parents or playmates how to mend their bikes, dismantle a machine or paint their constructs. She explains how she wants her makerspace facility to be an open workshop, not only for digital making, but also for activities resembling those of her youth, allowing students in her school district to get acquainted with or acquire some of the insights and skills involved.

Gerdur is an experienced teacher and teaching consultant leading the application of digital technologies and a makerspace under development in a rural school setting, a single school serving students from 6 to 15 years of age at three different sites. Teachers at all three sites can request assistance, but the consultant also suggests and runs projects involving making and digital media, often on a whole school basis. Gerdur has been setting up an open makerspace with an adjoining media lab and tempting teachers with project ideas involving integration and making:

We bought a vinyl cutter and I tricked the textiles teacher to give it a go and much enthusiasm was born. I informed her the next year about a course that she attended, and she is now adding diodes, lights, bells, electricity-STEAM things in textiles-to makeover clothes. I got her! (Gerdur)

Gerdur has taken agency, supported by her headmaster and assisted by her students, and turned a spacious classroom into a permanent makerspace and media center, a hub where teachers and students can come to get acquainted with maker technologies, experiment with robotics, try out vinyl cutting or 3D-printing, do green screen or stop-motion productions, broadcast their annual radio program for a few days or just find the space and shelter they might need for occasional project work involving tasks such as construction, painting or compositions. Innovation and STEM studies were already embedded in the school curriculum when Gerdur made her way to the school, after making sure that her consulting role and efforts to promote school development would be appreciated by the school leadership and receive its full support. Her participation in the team has also proven of exceptional value, considering her geographic isolation.

Sigyn, at the time a teacher at a large urban school in Reykjavik, took a different direction, starting small with the intension of gradually implementing and expanding her makerspace with her students at The Lab of Ingenuity (i. Snillismiðjan). This was an experimental model of instruction, 
carried out in collaboration with craft teachers and sustained in a set of rooms for 2 years. The aim was to introduce digital making to both students and teachers through skillful experts (i. snillingar) chosen from different age or class groups. The lab was equipped with a wide selection of digital tools, partly borrowed from other team members or Mixtura, the innovation and media center run by the city. The developmental model was to ask the experts to get into making and learn digital skills, which they then disseminated by offering lessons at the lab to small groups of selected peers. They would also, on occasions, reach out to the whole school community through social media or social events organized as educamps.

The experts visited the lab for a couple of class hours on a weekly basis to study new technologies and work on maker projects and programming tasks, mainly by applying digital tools such as micro:bits, Arduino kits, littleBits, Makey Makeyconnectors, an array of robots for different age levels, a 3Dprinter, special apps or programs to create visual presentations or video editing with special effects. They learned a bit about binary numbers and code with Scratch and MakeCode. They also tried their hands at VR, with Google's Tilt brush and Google Earth. The experts then got to invite classmates to the makerspace or lab where the they instructed their guests, assisting them with tasks they had just learned to complete themselves. Such a task might be to program a micro:bit computer with a visual block coding language to serve certain functions, such as applying a hydrometer to monitor soil dampness and create a happy or frowny face on the micro:bit to indicate results. Other tasks might involve the application of programmable robots like the Sphero or the Robot Mouse, creative work with technical kits like littleBits (Figure 3) or Arduino, use of specially chosen apps for the iPad or the Chromebook, or video editing with the help of a green screen. The whole practice was permeated by the idea that children can figure things out for themselves. Sigyn gave several accounts of how she created a space for students to solve problems and provided help with instruction. One story related how a group of sixth graders succeeded in setting up HTC Vive, a virtual reality system they had borrowed; another how the same group engaged in teaching visiting students from another school how to code a program to use with components from Arduino.

We observed how a group of four 8-year old experts took on a relatively rigid and pre-described task of programming, designed to instruct a hydro sensor to indicate the level of humidity in the potting soil surrounding a plant (Figure 4). The task did not allow for many creative moves, but the training session appeared to support autonomy, peer collaboration, and personalized learning. Sigyn appeared to supervise lab lessons for the experts in a "laisses faire" or hands-off fashion. She would let the children take charge, allow them to learn at their own speed, and only apply minimal guidance through illuminating questions, bits of information about crucial details or handouts with instructional guidelines.

This was also the case a few weeks later when the same group of students had to teach a group of selected peers how to solve this same task. Four 3rd grade experts played their role as a team of teachers with an intriguing authority. They asked Sigyn, their supervising teacher, for assistance when a malfunctioning device or a problematic programming detail would halt development or prevent progress, but this was always done in a casual manner as one would expect from a much older and more independent person. They would show initiative and resourcefulness when needed, they moved about freely and took charge of situations that needed to be handled or solved. The challenge of programming the micro:bit appeared to be a somewhat restricted task but perhaps also appropriately difficult for children 8 years of age.

We observed how eager the tiny experts were to showcase their expertise and teach their schoolmates, at educamps, while also noting how they tended at times to teach their peers by giving step-by-step instructions without using the proper terminology or explaining to what end the task at hand was undertaken. A 7 years old was observed teaching her classmates how to use a robot mouse, showing them how to lead the mouse the right way and carefully holding her finger over the start button to prevent her students from setting the mouse off before they had finished their coding. Teachers and parents were invited to attend the educamps. This would sometimes lead to increased support of parents and family involvement.

We observed how both boys and girls were actively involved when learning to code and later instructing their peers. The girls seemed to show greater initiative and authority in the role of an instructor, guiding individual learning and managing social interactions or classroom organization. Examples were seen of both genders looking for advice and help from their fellow instructors. The most difficult student groups to involve, according to Sigyn, were young boys and teenage girls.

Sigyn took care to exhibit student work and introduce student efforts to the wider community through social activities and social media. She also related how students tried to impress her with good behavior to stand a better chance of being allowed to visit the lab. The Lab of Ingenuity appeared to be an intriguing example of how makerspaces can be established in schools and developed in a way that allows teachers to attend to underprivileged students or in need of special attention, yet able to become active learners willing to help their peers and take on the role of a supportive instructor. The teacher had developed a model of expanded learning built on valuing students' experiences, enabling students to study digital technologies in a carefully structured makerspace and become ambassadors of making in their school community.

The model drew considerable attention in the compulsory school sector and helped to spark interest in making but was nevertheless abandoned after changes in school leadership. Sigyn moved on to a consulting position at a compulsory school in a neighboring municipality and has been applying for positions as a headmaster, a role that would allow her to influence school practice in a more profound way.

\section{Mixtura - A Digital Media and Innovation Center}

Two members of the team, Idunn and Nanna, were working as project managers and teaching consultants for the city of Reykjavík, as the team was established back in 2016. They had been hired by the municipality to provide professional 


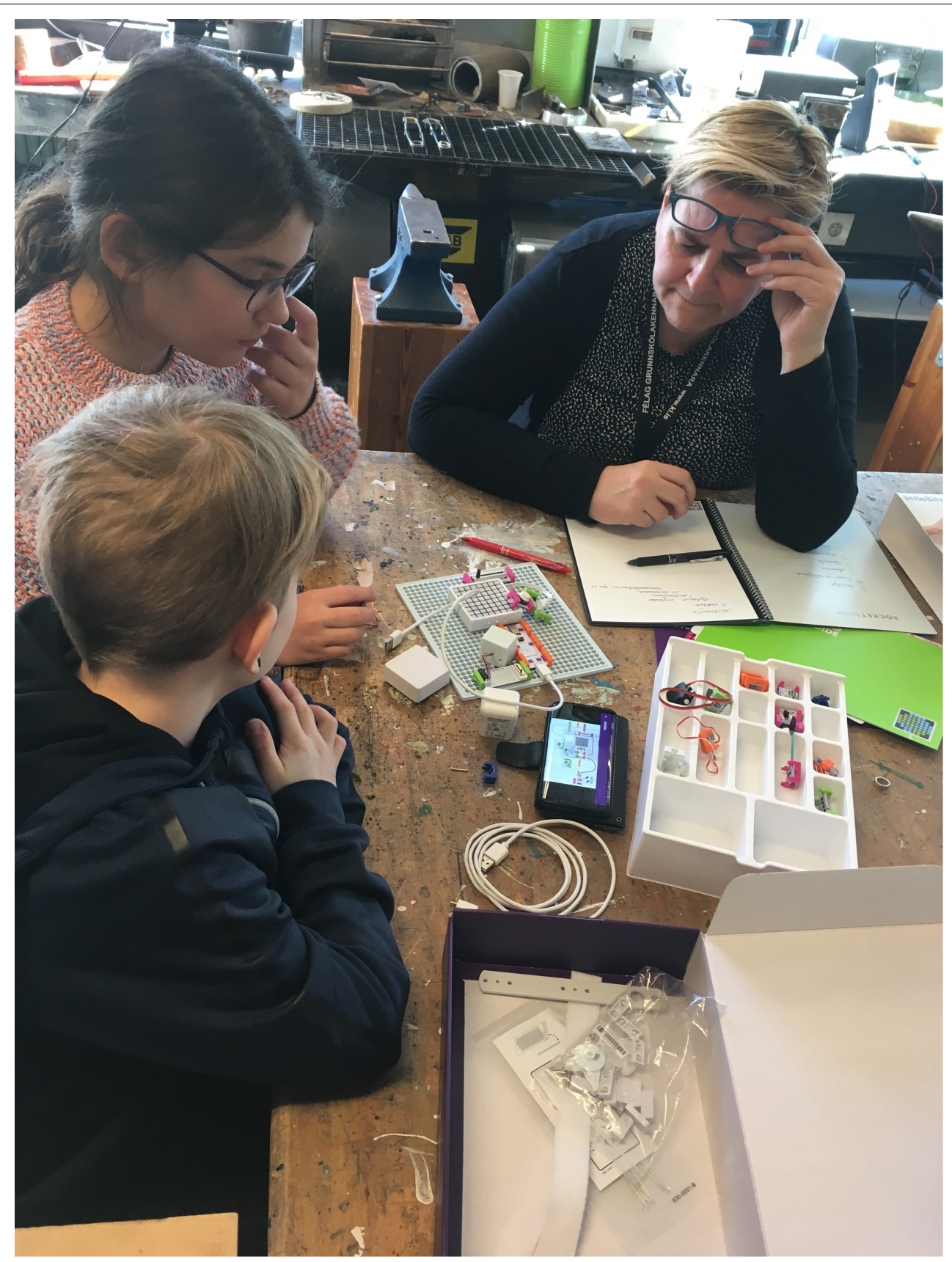

FIGURE 3 | Two students preparing to serve as skillful experts instructing peers how to use a set of littleBits in the Lab of Ingenuity at a compulsory school in Reykjavik.

guidance and lend out technical equipment to teachers in the field. A consulting center with a developmental technology and media lab called Mixtura is maintained by the city and has purchased or procured a variety of digital tools and making resources applicable at the preschool and compulsory school levels. Two other members, Freyja and Frigg, have now joined their grassroots teammates and taken on positions representing the city and the center. The center offers different courses on digital technologies and has of late been promoting making in a manner that might appeal to practicing teachers:

we are trying to find our niche, we do not want to be just like a Fab lab [...] we are trying to [purchase] things that appeal to teachers [...] something that can fit into many school subjects, is hands-on and allows for alternative ways of learning. (Idunn)

This ambition found in the city of Reykjavik to support making among practicing teachers holds some promise. It 


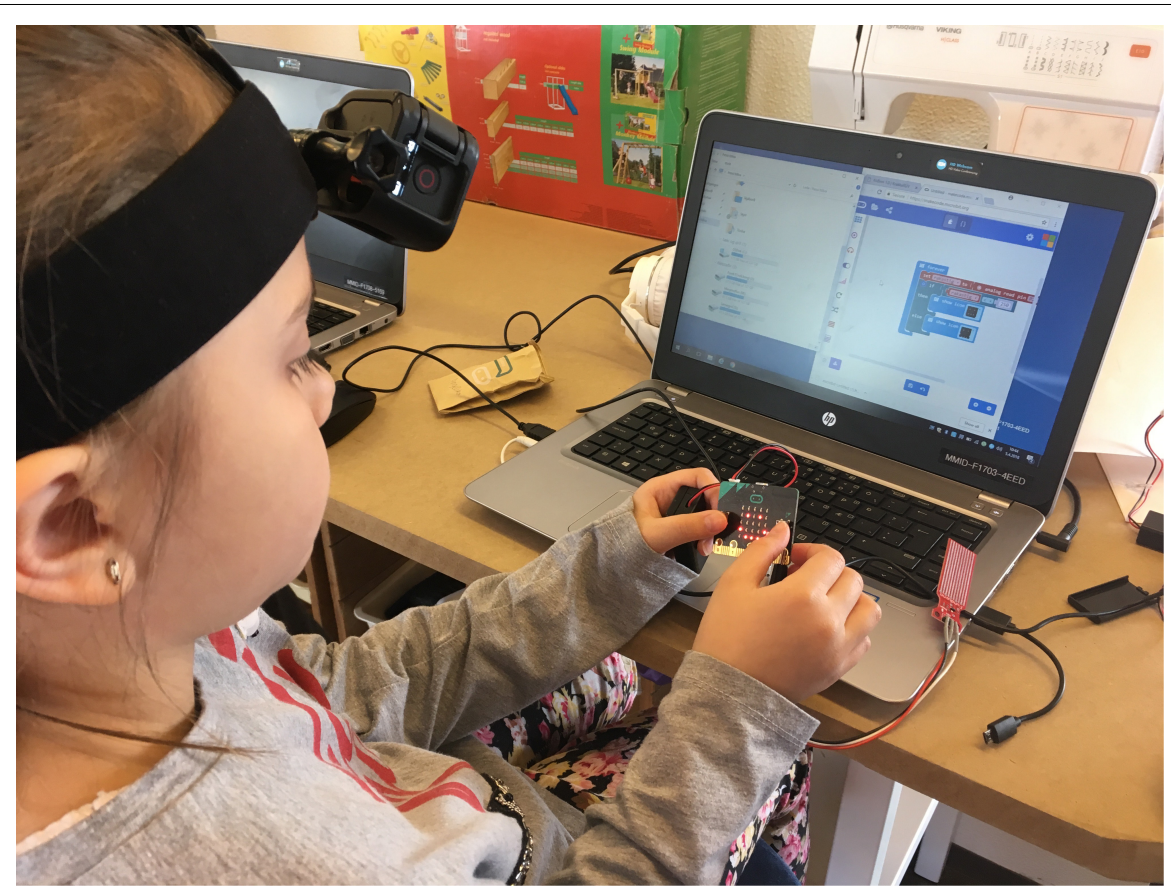

FIGURE 4 | A student preparing to serve as a skillful expert instructing peers how to program a micro:bit computer. The Go Pro-camera mounted on her head is there for research purposes.

must, however, be kept in mind how fragile the future of such a center can be. Frigg held before a teaching consultant position in a neighboring municipality, where she coordinated the introduction of tablets into school practice. She had been able to influence teachers at two of the schools involved to include making in their practice:

The staff that engages in makerspaces needs to be interested, because this is new to most people. Something that we have not had before in our system. We need somebody who dares, wants, but first and foremost, the headmaster needs to be interested and willing to find the right people for the job. (Frigg)

Her plans for setting up a central makerspace and technology center for schools in the municipality were welcomed at first by municipal authorities but fell through after some consideration. She consequently left her job to continue her constructive work on makerspaces and digital technologies elsewhere, at the center in Reykjavik, where her grassroots teammates were already professionally active.

\section{Gender and Makerspaces}

We will below highlight findings reflecting how gendered aspects appear to affect girls as participants in makerspaces and how participation in the team of seven female pioneers has helped team members to gain ground as professionals and leaders in the compulsory schoolteacher community.

\section{Girls in Makerspaces}

Girls and making was an issue raised by the team, Freyja and Sigyn point out how teenage girls tend to avoid elective classes focusing on technology and making. Freyja carried out an experiment one schoolyear, of teaching boys and girls separately in a design and innovation course. She allowed her students to choose from a few themes to look for gender priorities:

I decided to put in computer hacking [despite few votes], because the girls had a stronger interest for that than the boys. In retrospect, I would have let the voting form the curriculum entirely as to what each gendered group selected, but I had to make a compromise. (Freyja)

Sigyn, on the other hand, suggests obligatory making for all and special sessions to serve as eye-openers: "I think the girls just don't get it, that this is something for them [...] maybe we should have creative Fridays, where we introduce making to everyone." Idunn makes a point of illustrating how intimidating machinery can be, even to women such as herself, by revealing how she preferred a small vinyl cutter to a large and "scarier" model.

Gerdur tells us of girls who despite their strong character prove to be afraid of making mistakes when it comes to experiments or trials with technology: "I say: Just try! But they do not dare, I don't know, we need to get this out of them somehow." Nanna, in contrast, draws a strikingly different picture of the other gender: "the boys-and this I have noticed these past 5 years-are much more vocal, suggesting they have more knowledge [than girls] of something related to technology. But then you find out that they have little to build on." She later compares: "The girls just aren't as declarative in general, okay. More careful in giving out what they know and what not, in case they were wrong." And Freya reflects: "but then I think about it, when we are producing digital artifacts: they have more finesse, laying out photos and text. Such things. I 
think they are way ahead of the boys in paying attention to detail." Then she gives the girls even more credit:

I liked watching them in computer hacking. Many of them had [already] done this and that, taken a computer apart or something. You often presume that they have done less than... Some of them have fathers who have done things with them or [the girls have] gone on courses.

Our findings confirm a gendered difference in student choices and reveal that careful reflection is needed when teachers review learners, especially regarding competences that girls may have. This requires close attention to gendered interest, and a consistent effort to facilitate choice and participation.

\section{Women in the Team as Makers and Educational Leaders}

Women in the team have acted as leaders in the Icelandic teacher community, actively promoting digitalization, making, librarianship, and collaboration in educational practice. They have gradually moved from teacher positions to counseling and project management. They are ambitious and mobile, most of them have considerable organizational influence as consultants in their municipalities and some have revealed their ambition to become school leaders, in order to position themselves to make the changes needed to evolve alternative pedagogical models and nudge school development toward digitalization and making. Sif has now taken on the role of a headmaster at her school and maintains that her reputation as a team member must have helped her to get that position.

All team members describe how participation in the group has benefitted them professionally and boosted their individual and collective activities:

\section{This was something else, there was something happening, we were all of a sudden simply a community of practice, I thought it was really nice, there is a kind of power and synergy in the collaboration, and we keep challenging ourselves. (Idunn)}

For some the group has broken their geographical or institutional isolation while others see it as being the nutrient, they needed to forge on in their maker activities. The team has become an important part of their ongoing professional development through experiments, shared experiences and project descriptions. Collective efforts appear to benefit team members greatly. Freyja states: "our best professional development takes place when we decide to develop a course [together] and we need to find out how to deliver it." We observed how the group searched for knowledge or ideas, experimented with new technologies and created both conceptual and material objects, that they employed in their consultancy and course development.

Being dissimilar individuals with various work duties appears to have created an important and dynamic learning situation. Idunn: "A special atmosphere is created, we learn a lot from each other, they are brilliant professionals [...] it is invaluable to connect with progressive individuals in the field when forming or enforcing a policy." The collaboration takes many forms and we were able to observe this atmosphere, both in group interviews, in course delivery and on social media. It was characterized by laughter, almost girlish giggles and spontaneity, joy of learning and togetherness, though always with a clear focus on the job at hand.

Team members were asked why they had chosen not to include any men in their team. Some maintain that they had not paid this much thought, while others admit that this could possibly be attributed to a certain degree of feminism within the group. Sif, who initiated the first group meeting, confirms that notion:

\section{it is without a doubt certain feminism. But [...] this resonates the state of the profession, where women are in majority. And the group would never have operated in the way it does if men had been included.}

She remarks, that the men who might have been considered as potential members when the group was being formed, were at the time either too advanced in terms of technical knowhow or in other cases, too arrogant and dominant in their approach to technology and school development. Some of the members proclaim that they had nothing against men and pointed out that they themselves had often organized events and courses with men. Others take a somewhat different stance, pointing out how male educators tend to dominate the scene when it comes to digital technologies in education, Sigyn says: "I was tired of this [...] there were only men sharing [...] I simply made a conscious decision that year, to share everything." This willingness to share, collaborate and connect with others characterizes the team, a trait considered typical, not only of women groups, but also the culture of the maker movement.

\section{DISCUSSION AND CONCLUSION}

We have set out to explore what characterizes the personal standpoints, beliefs and practices within the team, regarding the purpose and value of makerspaces. Furthermore, how team members have worked toward promoting makerspaces and finally how their collective creativity has helped to advance their agency and professional development. These questions are discussed here in order, with an emphasis on the role of gender and challenges that still prevail.

\section{A Female Team of Pioneers}

The decision to form an all-women team to explore and promote making was an affirmative move and created an ambience where the women were able, in a friendly and sociable environment, to shape their ideas and activities. Extensive experience of teaching, new technologies, developmental work, leadership and counsel was a great asset for all team members and the team itself. Their dedication and enthusiastic disposition regarding change and school development was also noteworthy. Together, they were able to carve out an agenda, at their respective workplaces, gain support and create an internet platform to introduce makerspaces. In that way they acted as change-agents and forward-looking activists (Stetsenko, 2018). Collaboration and substantial knowledge building (Hughes et al., 2019) could be seen to release a collective creativity 
(Sannino and Ellis, 2014: Stetsenko, 2018) that produced various resources and achievements.

By taking the initiative and asserting transformative agency (Emirbayer and Mische, 1998; Stetsenko, 2018), the team started a trend in school development and assisted interested teachers in attempting new educational moves, developing pedagogies and harnessing digital technologies. The team has been creative in its approach and in effect provided female leadership in a field that has often been considered male dominated (Wajcman, 2010). Team members have in female collaboration attempted to bring about a cultural transformation within the teaching profession at the primary and lower secondary level of schooling, leading the way for others, based on their own experience and communal resources, with the maker movement in broader terms and technology as a source. Mutual support, friendly interaction, liveliness and collective creativity (Sannino and Ellis, 2014), related in many interviews and reflected in Facebook data, appear to have played a leading role in this regard. Members have, through self-directed learning, managed to acquire and build their expert knowledge about makerspace technologies, operational skills and design literacy (Oliver, 2016). They have established diverse makerspaces in different educational contexts, organized workshops and courses and harnessed social media and digital communities to share their contributions with teachers nationwide, providing favorable conditions for expanded learning (Engeström, 1987) of making and maker culture (Vossoughi and Escudé, 2016; Kim et al., 2018). In that way the team has enabled its members to extend their network and create new professional opportunities for themselves and others, and as such encouraged their agency and empowered individuals.

It is tempting to argue that an evident and growing trend toward sharing and interactive consultancy among teachers as professionals should help to ease the way for making in schools. This might apply particularly well to women, who make up the bulk of teachers in compulsory schools and are as a gender group considered likely to collaborate, share experiences and assist each other under challenging circumstances (Sannino and Ellis, 2014). We might even argue that makerspaces could manifest an opportunity for female teachers to show their strength in this respect.

\section{Implementation of Makerspaces}

The Icelandic curriculum (Ministry of Education Science and Culture, 2014) encourages making and integration of subjects such as STEM and STEAM and the team has made good progress in connecting curricular aims to the practice of makerspaces in schools. Members have emphasized development of 21 st century skills, highlighted diverse needs and interests of learners, and encouraged collaboration, issues prominent in the core curriculum and reflected in its fundamental pillars of education. They have developed different models of makerspaces, with examples ranging from a consultancy/training center serving a large municipality to makerspaces at school set up by a single teacher or a librarian.

One might suspect that lack of funding would be considered a barrier hindering the implementation of makerspaces, but our data did not reveal this as holding back development. Our research findings confirm other challenges, outlined by Hira et al. (2014), i.e., the stronghold of standardized testing, teacher preparation and integration of technology. We observed how team members trying to interest their fellow teachers had more success with those in art and craft, subjects not dependent on standardized testing and with a rich making tradition (Ólafsson and Thorsteinsson, 2013). Subject curricular demands and rigid timetables made technical advancements and integrated project work difficult to implement without special arrangements. This causes concern since making in academic subjects could help to spur a wider interest of learners in the subject areas in question and offer creative, transdisciplinary ways for knowledge building and development of digital literacy, called for in the national core curriculum (Ministry of Education Science and Culture, 2014). The research reveals reluctance of academic subject teachers to develop experimental and collaborative learning sessions together with makerspace facilitators. The demand to cover curricular learning materials appeared more important to the academic teachers, than experimental and creative work involving digital technologies and literacies. It remains in effect a considerable challenge to provide students with the appropriate flexibility and freedom for ideation, design, experimentation and meaning making (Bauersfeld, 1995; Gunnarsdóttir, 2001; Thorsteinsson, 2013; Jónsdóttir and Gunnarsdóttir, 2017). More research is needed to develop and document examples of making as a tool for this purpose.

We paid special attention to The Lab of Ingenuity, which empowered students at a young age to become instructors of new technologies and digital literacies, allowing the lab to bring knowledge, skills and entrepreneurship into their school community. The pedagogy of the lab is an expansive model (Engeström, 1987), based on experiential, problembased, personalized learning, supported by peers (Corsaro, 1997; Blikstein, 2013; Smith and Smith, 2016). With the assignment of equal numbers of boys and girls from all classes at school to study and disseminate their learning, steps were taken to build a culture of equity in digital making, as well as establish a sense of social belongingness and self-efficacy (Tellhed et al., 2017) among underprivileged students. The model appears to have the potential for developing a learning culture of snowballing dissemination but might not be altogether sustainable within a school with limited means of funding or strict curricular demands. The model was abandoned, allegedly due to organizational changes and staff mobility.

The model most team members saw as feasible for establishing makerspaces in schools was an open space with a teaching consultant, where the space and the practice are adapted to learning objectives already planned by teachers and students. A setting or space like that can be organized and equipped to create a learning culture based on intended learning and student involvement, as suggested by Kim et al. (2018). The idea of makerspaces enhancing academic learning and knowledge building calls for collaborative practices in various forms, often involving an integrated approach across subject areas (Drake and Burns, 2004) in ways that need to be further explored. The idea of a makerspace as an open venue for students or teachers to 
use at will based on interest, free choice or selection of tasks, is also a developmental track that evokes significant questions and calls for exploration. The team has already developed and exhibited diverse examples of how a school makerspace can be laid out in practice and continues to look for ways to bring project work aiming for skillful design and design literacy beyond overtly constrained tasks or prescriptive making.

\section{The Gender Perspective}

Gender identity is socially constructed in various life situations, including schools. The research of Guiso et al. (2008) related that social conditioning and gender-biased environments can have a large effect on test performance. Their research results indicated that in more gender equal countries (with a high GGI) girls tend to perform better than boys in maths and much better in reading. This might suggest that a gender-equal culture could have an equalizing effect in other subject areas of education. We have underlined how gendered factors can prevent inclusion and equal access to new technologies (Kim et al., 2018). Both teachers and students may have interests and demands, that differ according to gender. Trainers and advocates of making will need to take this into account in their choice of pedagogical models and teaching plans for makerspaces. Understanding the dynamics and opportunities within makerspaces means looking at the culture, practices and support structures, as well as experiences, life histories and backgrounds of participants, from a techno-feminist perspective (Wajcman, 2010). We as educators and researchers see it as important to make learners feel that they fit in and have self-efficacy, particularly women and girls, that sometimes feel excluded from the field.

The exposure of learning processes and learning results to parents and other interested partners also appears likely to expand the learning options and create a supportive environment for the making (Barron et al., 2009; Dýrfjörð et al., 2020). A pedagogical approach, emphasizing personalized learning and applying instructional models where diversity and the agency of students is respected and encouraged, could create favorable conditions for learning through making activities irrespective of gender and different abilities. All actions to support equality and inclusion count, as the example of the Lab of ingenuity suggests, where agency and leadership were actively encouraged and steps were taken to build an equalitarian culture of digital making accessible for both boys and girls, social belongingness and self-efficacy (Tellhed et al., 2017).

It is worth considering how makerspaces in schools can support the progress of girls in technology-related subject areas. Our findings show how girls are hesitant to work with technology, fearing failure or losing interest. They do, however, also reveal how makerspaces might serve as a feasible venue for women to express their collaborative skills and collective assertiveness. Previous research has indicated that making changes perception of learning (Vossoughi and Bevan, 2014), leading students to value the process of making and failure. Our data suggests that girls appear to be too focused on outcome and good grades, performing according to accepted norms, and underlines how the inclusion of making emphasizing process rather than product might help them cultivate courage and agency to make their way in STEM and STEAM learning. This is particularly important bearing in mind research indicating a more negative impact of learning hindrances on girls (Gbollie and Keamu, 2017).

Significant social and financial support from school managers, local authorities and companies assisted the construction of some of the makerspaces in this research and provided opportunities for exposure of achievements of the team. Lack of manager vision and undecisive school curriculum, management inability to act and resistance of local government to change was also observed. In those cases, efforts were not appreciated or rewarded, and individual team members met with several challenges. Findings reflected in Table 1 show how four out of seven team members changed their workplaces over the last few years. This can be interpreted either way as a sign of failure or agency, as a woman decides to find herself a new venue for her drive and enthusiasm in developing new educational opportunities. The literature on teacher mobility, however, has mostly focused on early career teachers and current teacher mobility theories do not explain all factors affecting such decisions (Vagi and Pivovarova, 2016). It is a cause for concern if pioneers are not given space to carry out their vision and even more worrying if their gender is the obstacle preventing dedicated educators to become vital role models for an underrepresented group in science and technology (Noonoo, 2018).

Women's lives have undergone dramatic changes during the twentieth century, rendering traditional sex roles untenable (Wajcman, 2010). This coupled with developments of technology, such as open access and social media have created opportunities for participation and action, irrespective of gender, and prompted visionary thinking. By deciding to form an all-female group the team members released themselves from conventional social settings and norms and created their own space for action, providing an ambience where male dominance did not play a role. Mutual support within the team proved important, and is reflected in joyful meetings, social activities, dynamic conversations, rewarding exchanges of information and encouragement through social networking and learning (Smith and Smith, 2016).

The collaborative efforts and developmental work of the team of seven pioneers is still evolving, growing in strength. It remains to be seen how successful the group will be in future efforts to promote the application of makerspaces into Icelandic schools. The team has already made a significant difference in this regard and demonstrates the value of bringing together enthusiastic women leaders dedicated in their development for innovative teaching methods, new technologies and advanced project ideas to apply in daily school practice. The allfemale aspect of the group is even more interesting and should be explored further in future research. Our research, of course, is contextually limited to Icelandic conditions that could be regarded exceptionally favorable in terms of gender equality but the empowerment of women seems to become more apparent with every new initiative where groups of women take agency and make their achievements known. 
A growing interest in digital technologies and making in compulsory school education coincides with that trend at many different levels.

\section{DATA AVAILABILITY STATEMENT}

Datasets from this research project are preserved in an open repository of the MakEY project: https://makeyproject.eu/.

\section{ETHICS STATEMENT}

The studies involving human participants were reviewed and approved by the Scientific Committees at the University of

\section{REFERENCES}

Barron, B. (2006). Interest and self-sustained learning as catalysts of development: a learning ecology perspective. Hum. Dev. 49, 193-224. doi: 10.1159/00009 4368

Barron, B., Martin, C. K., Taeuchi, L., and Fithlan, R. (2009). Parents as learning partners in the development of technological fluency. IJLM, 1, 55-77.

Bauersfeld, H. (1995). "The structuring of the structures: development and function of mathematizing as a social practice," in Constructivism in Education, eds L. P. Steffe and J. Gale (Hillsdale, NJ: Lawrence Erlbaum Associates Publishers).

Blikstein, P. (2013). "Digital fabrication and 'making' in education: the democratization of education," in FabLab: Of Machines, Makers and Inventors, eds J. Walter-Herrmann and C. Buüching (Berlin: Kultur- und Medientheorie).

Braun, V., and Clarke, V. (2013). Successful Qualitative Research: A Practical Guide for Beginners. London: Sage.

Clapp, E. P., Ross, J., Ryan, J. O., and Tishman, S. (2017). Maker-Centered Learning: Empowering Young People to Shape Their Worlds. Hoboken, NJ: John Wiley \& Sons.

Corsaro, W. A. (1985). Friendship and Peer Culture in the Early Years. Westport: Ablex Publishing.

Corsaro, W. A. (1997). The Sociology of Childhood. Thousand Oaks, CA: Pine Forge Press.

Costa, M. C. D. (2008). Technofeminism - Judy Wajcman. Electronic J. Commun . Inf. Innov. Health 2, 108-109. doi: 10.3395/reciis.v2i2.225en

Dakers, J. R. (2014). Defining Technical Literacy, 2nd Edn. New York, NY: Palgrave Macmillan.

Demetriadis, S., Barbas, A., Molohides, A., Palaigeorgiou, G., Psillos, D., Vlahavas, I., et al. (2003). "Cultures in negotiation": teachers' acceptance/resistance attitudes considering the infusion of technology into schools. Comp. Educ. 41, 19-37. doi: 10.1016/S0360-1315(03)00012-5

Drake, S. M., and Burns, R. C. (2004). "What is integrated curriculum?," in Meeting Standards Through Integrated Curriculum, eds S. M. Drake and R. C. Burns (Alexandria, VA: Association for Supervision and Curriculum Development).

Dýrfjörð, K., Hjartarson, T., Hreiðarsdóttir, A. E., Jakobsdóttir, S., Jónsdóttir, S. R., Kjartansdóttir, S. H., et al. (2020). "Makerspaces in formal and non-formal learning contexts in Iceland," in Makerspaces in the Early Years: Enhancing Digital Literacy and Creativity, eds A. Blum-Ross, K. Kumpulainen, J. Marsh, and K. Thestrup (Abingdon: Routledge). doi: 10.4324/9780429243264-6

Emirbayer, M., and Mische, A. (1998). What is agency? Am. J. Sociol. 103, 9621023. doi: $10.1086 / 231294$

Engeström, Y. (1987). Learning by Expanding an Activity - Theorethical Approach to Developmental Research. Available online at: http://lchc.ucsd.edu/mca/Paper/ Engestrom/expanding/toc.htm (accessed May 7, 2011).

Gbollie, C., and Keamu, H. P. (2017). Student academic performance: the role of motivation, strategies, and perceived factors hindering liberian junior and senior high school students learning. Hindawi. Educ. Res. Int. 2017:1789084. doi: $10.1155 / 2017 / 1789084$
Sheffield and the University of Iceland. Written informed consent was obtained from the individual(s), and minor(s)' legal guardian/next of kin.

\section{AUTHOR CONTRIBUTIONS}

All authors listed have made a substantial, direct and intellectual contribution to the work, and approved it for publication.

\section{FUNDING}

This research was partly funded by the European Commission Horizon 2020 Programme, Grant No: 734720.

Gjersoe, N. (2018). Bridging the Gender Gap: Why do so Few Girls Study STEM Subjects? To Attract More Girls to Study STEM Subjects at University, We Need to Tackle the Stereotypes They are Exposed to Early On. London: The Guardian.

Green, E., and Singleton, C. (2013). "'Gendering the digital': the impact of gender and technology perspectives on the sociological imagination," in Digital Sociology, eds K. Orton-Johnson and N. Prior (London: Palgrave Macmillan), 34-50. doi: 10.1057/9781137297792_3

Guiso, L., Monte, F., Sapienza, P., and Zingales, L. (2008). Diversity. Culture, gender, and math. Science 320, 1164-1165. doi: 10.1126/science.115409

Gunnarsdóttir, R. (2001). Research in innovation education: socio-cultural methods for research and analysis for defining educational phenomenon. visions on sloyd and sloyd education. Techne Ser. Res. Sloyd Educ. Crafts Sci. B 10, 65-104.

Hennessey, S., and Deaney, R. (2004). Sustainability and Evolution of ICT Supported Classroom Practice. Cambridge: University of Cambridge.

Hira, A., Joslyn, C. H., and Hynes, M. M. (2014). "Classroom makerspaces: identifying the opportunities and challenges," Paper Presented at the Frontiers in Education Conference (FIE) in 2014 IEEE, Madrid. doi: 10.1109/FIE.2014. 7044263

Hughes, J., Morrison, L., Kajamaa, A., and Kumpulainen, K. (2019). "Makerspaces promoting students' design thinking and collective knowledge creation: examples from Canada and Finland," Paper presented at the 7th EAI International Conference, ArtsIT 2018, and 3rd EAI International Conference, DLI 2018, ICTCC 2018, Braga. doi: 10.1007/978-3-030-06134-0_38

Iversen, O. S., Smith, R. C., Blikstein, P., Katterfeldt, E.-S., and Read, J. C. (2016). Digital fabrication in education: expanding the research towards design and reflective practices. Int. J. Child Comp. Interact. 5, 1-2. doi: 10.1016/j.ijcci.2016.01.001

Jónsdóttir, K. (2020). Kvennalistinn [Womens' list]. Available online at: http:// kvennalistinn.is/ (accessed July 25, 2020).

Jónsdóttir, S. R. (2011). The Location of Innovation Education in Icelandic Compulsory Schools. PhD thesis. Reykjavík: University of Iceland.

Jónsdóttir, S. R., and Gunnarsdóttir, R. (2017). The Road to Independence: Emanicipatory Pedagogy. Rotterdam: Sense Publishers. doi: 10.1007/978-946300-800-6

KEA (2009). The Impact of Culture on Creativity: A Study Prepared for the European Commission. Available online at: https://keanet.eu/wp-content/uploads/2019/ 09/impactculturecreativityfull.pdf.

Keune, A., Peppler, K. A., and Wohlwend, K. E. (2019). Recognition in makerspaces: supporting opportunities for women to "make" a STEM career. Comput. Human Behav. 99, 368-380. doi: 10.1016/j.chb.2019.05.013

Kim, Y. E., Edouard, K., Alderfer, K., and Smith, B. K. (2018). Making Culture: A National Study of Education Makerspaces. Philadelphia, PA: Drexel University.

Kontopodis, M., and Kumpulainen, K. (2020). "Researching young children's engagement and learning in makerspaces: insights from post-vygotskian and post-human perspectives," in Enhancing Digital Literacy and Creativity: Makerspaces in the Early Years, eds A. Blum-Ross, J. S.-G. Kristiina 
Kumpulainen, and J. Marsh (Abingdon: Routledge), 11-23. doi: 10.4324/ 9780429243264-2

Kristmundsdóttir, S. D. (1989). "Outside, muted, and different: icelandic women's movements and their notions of authority and cultural separateness," in The Antropology of Iceland, eds E. P. Durrenberger and G. Pálsson (Iowa: University of Iowa Press), 80-97. doi: 10.2307/j.ctt20fw942.9

Law nr. 56/2017 (2017). Law on Amendment of Law on Equal Rights of Men and Women [i. Lög um breytingu á lögum um jafna stöðu og jafnan rétt kvenna og karla]. Althingi [The National Parliament of Iceland].

Law nr. 78/1976 (1976). Law on Equal Rights of Men and Women [i. Lög um jafnrétti kvenna og karla]. Althingi [The National Parliament of Iceland].

Leal Fonseca, D. (2011). EduCamp Colombia: social networked learning for teacher training. Int. Rev. Res. Open Dist. Learn. 12, 60-79. doi: 10.19173/irrodl.v12i3. 884

Makerspace á Íslandi (n.d.). Available online at: https://www.facebook.com/ groups/664271910444072/

MakEY (2018). Makerspaces in the Early Years: Enhancing Digital Literacy and Creativity (MakEY). Available online at: https://sites.google.com/a/sheffield.ac. uk/makey_project/home (accessed September 29, 2018).

Marsh, J., Kumpulainen, K., Nisha, B., Velicu, A., Blum-Ross, A., Hyatt, D., et al. (2017). Makerspaces in the Early Years: A Literature Review. Sheffield: University of Sheffield.

Maslyk, J. (2016). STEAM Makers. Fostering Creativity \& Innovation in the Elementary Classroom. Thousand Oaks, CA: Corwin.

Ministry of Education Science and Culture (2014). The Icelandic National Curriculum Guide for Compulsory Schools - With Subject Areas. Reykjavik. Ministry of Education, Science and Culture.

Nasciutti, F. M. B., Veresov, N., and Aragão, A. M. F. D. (2016). The group as a source of development: rethinking professional development in a collaborative perspective. Outl. Crit. Pract. Stud. 17, 86-108.

National Statistical Institute of Iceland (2020). Available online at: https://hagstofa (accessed July 27, 2020).

Noonoo, S. (2018). Maker Culture has a 'Deeply Unsettling' Gender Problem. Available online at: https://goo.gl/SPB41N (accessed July 15, 2020).

Nýsköpunarmiðstöð Íslands (2018). FABLAB ÍSLAND - Um Fab Lab. Vestmannaeyjar: FABLAB Island.

Ólafsdóttir, K., and Rögnvaldsdóttir, S. (2015). Staða kvenna og karla á islenskum vinnumarkaði: Staðreyndir og staða pekkingar. Available online at: https://www.stjornarradid.is/media/velferdarraduneyti-media/media/ritog-skyrslur-2015/Stada_karla_og_kvenna_29052015.pdf (accessed July 16, 2020).

Ólafsson, B., and Thorsteinsson, G. (2013). Design and craft education in iceland, pedagogical background and development: a literature review. Design Technol. Educ. 14, 10-24.

Oliver, K. M. (2016). Professional development considerations for makerspace leaders, part one: addressing "What?" and "Why?". TechTrends 60, 160-166. doi: $10.1007 / \mathrm{s} 11528-016-0028-5$

Sannino, A., and Ellis, V. (2014). "Activity-theoretical and sociocultural approches to learning and collective creativity: an introduction," in Learning and Collective Creativity, eds A. Sannino and V. Ellis (New York, NY: Routledge). doi: 10.4324/ 9780203077351

Sawyer, R. K., and DeZutter, S. (2009). Distributed creativity: how collective creations emerge from collaboration. Psychol. Aesthet. Creat. Arts 3, 81-92. doi: $10.1037 / \mathrm{a} 0013282$

Sheridan, K., Halverson, E. R., Litts, B., Brahms, L., Jacobs-Priebe, L., and Owens, T. (2014). Learning in the making: a comparative case study of three makerspaces. Harvard Educ. Rev. 84, 505-531. doi: 10.17763/haer.84.4.brr3473372 $3 j 648 \mathrm{u}$

Sköpunarsmiðjur (n.d.) Sköpunarsmiðjur. Samstarfsverkefni um Sköpunarsmiðjur i Vesturbcejarskóla, Ingunnarskóla og Selásskóla. Available online at: https://sites. google.com.rvkskolar.is/austurvestur/heim
Smith, W., and Smith, B. C. (2016). Bringing the maker movement to school. fourth grade students create projects to illustrate the transfer and transformation of energy. Sci. Child. 54, 30-37.

Spelke, E. S. (2005). Sex differences in intrinsic aptitude for mathematics and science? A critical review. Am. Psychol. 60, 950-958. doi: 1037/0003-066X.60. 9.950 ,

Stake, R. (1995). The Art of Case Study Research. Thousand Oaks, CA: Sage Publications.

Stetsenko, A. (2018). "Creativity as dissent and resistance: transformative approach premised on social justice agenda," in The Palgrave Handbook of Social Creativity Research, eds I. Lebuda and V. Glaveanu (London: Palgrave). doi: 10.1007/978-3-319-95498-1_26

Stetsenko, A., and Ho, P.-C. G. (2015). The serious joy and the joyful work of play: children becoming agentive actors in co-authoring themselves and their world through play. Int. J. Educ. Cult. 47, 221-234. doi: 10.1007/s13158-015-0141-1

Styrkársdóttir, A. (1999). From Feminism to Class Politics - The Rise and Decline of Women's Politics in Reykjavík 1908-1922. Umeå: Umeå University.

Tan, M. (2018). When makerspaces meet school: negotiating tensions between instruction and construction. J. Sci. Educ. Technol. 28, 75-89. doi: 10.1007/ s10956-018-9749-x

Tellhed, U., Bäckström, M., and Björklund, F. (2017). Will i fit in and do well? The importance of social belongingness and self-efficacy for explaining gender differences in interest in STEM and HEED Majors. Sex Roles 77, 86-96. doi: 10.1007/s11199-016-0694-y

The Nmc/CoSN Horizon Report (2017). Available online at: https://cdn.nmc.org/ media/2017-nmc-cosn-horizon-report-k12-EN.pdf (accessed November 25, 2018).

Thorsteinsson, G. (2013). "Developing an understanding of the pedagogy of using a virtual reality learning environment (VRLE) to support innovation education," in The Routledge International Handbook of Innovation Education, ed. L. Shavinina (Oxford: Routledge), 456-470.

Trainor, A. A., and Graue, E. (eds) (2013). Reviewing Qualitative Research. New York, NY: Routledge. doi: 10.4324/9780203813324

UNESCO (2017). Cracking the Code: Girls' and Women's Education in Science, Technology, Engineering and Mathematics (STEM). Paris: UNESCO.

Vagi, R., and Pivovarova, M. (2016). "Theorizing teacher mobility": a critical review of literature. Teach. Teach. 23, 781-793. doi: 10.1080/13540602.2016.1219714

Vexa Group (n.d.). Snillismiðjur [i. Labs of Ingenutiy, Makerspaces]. Available online at: https://sites.google.com/rvkskolar.is/snillismidjur

Vossoughi, S., and Bevan, B. (2014). Making and Tinkering: A Review of the Literature. Available online at: http://sites.nationalacademies.org/cs/groups/ dbassesite/documents/webpage/dbasse_089888.pdf (accessed June 30, 2020).

Vossoughi, S., and Escudé, M. (2016). Making through the lens of culture and power: toward transformative visions for educational equity. Harvard Educ. Rev. 86, 206-232. doi: 10.17763/0017-8055.86.2.206

Vygotsky, L. S. (1978). Mind in Society: The Development of Higher Psychological Processes. Cambridge: Harvard University Press.

Wajcman, J. (2010). Feminist theories of technology. Cambridge J. Econ. 34, 143-152. doi: 10.1093/cje/ben057

World Economic Forum (2019). Insight Report, Global Gender Gap Report 2020. Cologny: World Economic Forum.

Conflict of Interest: The authors declare that the research was conducted in the absence of any commercial or financial relationships that could be construed as a potential conflict of interest.

Copyright $\odot 2020$ Kjartansdóttir, Hjartarson and Pétursdóttir. This is an open-access article distributed under the terms of the Creative Commons Attribution License (CC BY). The use, distribution or reproduction in other forums is permitted, provided the original author(s) and the copyright owner(s) are credited and that the original publication in this journal is cited, in accordance with accepted academic practice. No use, distribution or reproduction is permitted which does not comply with these terms. 